\title{
'Nauseous Tides of Seductive Debauchery': Irish Story Papers and the Anti-Vice Campaigns of the Early Twentieth Century
}

The late nineteenth and early twentieth centuries saw an unprecedented rise in leisure reading in many countries, as universal education resulted in a mass market of upper-working class and lower-middle class leisure readers. This in turn led to an unprecedented surge in popular publishing, as new magazines and newspapers were established to appeal to these readers. Sporting magazines, miscellany papers for commuters, women's magazines, and story papers for juvenile readers all appeared in ever-greater numbers during the late Victorian and Edwardian era, and in turn created new cultures of leisure reading and advertisements, and new styles of journalism and interaction between editors and readers. ${ }^{1}$

London was the global centre of this publishing boom, whether of books, newspapers, or periodicals. And by the start of the twentieth century, efficient transport links meant that London publications - even daily newspapers whose currency depended upon their immediacy - could reach Ireland quickly and cheaply. Most British newspapers and magazines imported into Ireland were transported and distributed by Eason and Sons, a former subsidiary of the WH Smith company, which was bought out by its manager Charles Eason in 1886, but continued to operate as, effectively, the Irish branch of WH Smith's until well into the twentieth century. ${ }^{2}$ This bulk importation of multiple titles, using Eason's access to sea and rail networks, was what made it feasible for British publications such as the News of the World and Tit-Bits to be distributed to newsagents all across Ireland, and at more or less the same speed at which they were distributed across the rest of the United Kingdom. In December 1898, James Tallon's news agency on Grafton Street in Dublin published a large advertisement in the Freeman's Journal, listing the magazines 
and journals which they had in stock. More than 170 publications were listed, almost all of them of British origin. While it was highly unusual for a newsagent to provide such a comprehensive list of their stock in an advertisement, Tallon's range of publications would not have been at all unusual in a Dublin news agency by the turn of the twentieth century. As a result, Irish publications had to compete for readers with British publications which benefitted from enormous economies of scale - this was reflected in everything from the quality and quantity of illustrations they could provide, to the fame and popularity of the authors whose work was published, and the size of the prizes offered for reader competitions. ${ }^{3}$

This essay will focus upon the story papers produced in Ireland at this time, and in particular will argue that one of the ways in which they sought to compete with their larger and better-funded British equivalents was to align themselves with the powerful 'social purity' movement. Given that movement's condemnation of the very type of sensational fiction which story papers published, this would seem an unlikely alliance, but I will argue that in fact the Irish story papers and organisations such as the Irish Vigilance Association developed a symbiotic and profitable (if informal) relationship based upon their mutual antipathy to popular British publications.

Story papers had become a very significant publishing format well before the start of the twentieth century. Aimed principally at young male readers, but often read by entire families, they published short and serial fiction of various genres, including adventure tales, romances and historical fiction. Their readership was typically upper-working class or lower-middle class, as exemplified by the fact that many of them included columns offering advice on how to pass entrance examinations for the lower grades of the civil service, post office, and other junior clerical posts. Some of the most successful British story papers were Magnet, Gem, and the Boys Own Paper, and scholarly analyses of them have tended to focus upon their representations of a particular kind of imperial masculinity for young male readers, both before and after World War One. ${ }^{4}$

Scholarship on Irish media history, by contrast, has tended to focus upon political journalism, news reporting, and the more direct relationships between mass media and the developing Home Rule and nationalist movements of the late-nineteenth century. Topics such as political cartoons, the nationalist press, and the importance of the media in the rise and fall of Parnell have all received attention in recent years. ${ }^{5}$ By comparison, little attention has been paid to the popular entertainment press in Ireland at this time, which included sport, fashion, and fiction publishing. ${ }^{6}$ By the early twentieth century, there were at least four well-established story 
papers in Ireland - the Irish Emerald, the Shamrock (these two papers would merge in 1912), Ireland's Own, and the Irish Packet. Like most story papers internationally, they were penny weeklies aimed primarily at a juvenile male readership, but also positioned themselves as family papers, and included fiction and regular columns intended for younger female readers as well. Also like their international counterparts, their market was clearly the upper-working class and lower-middle class, the readership which was benefitting from universal basic education, and which was now the numerical majority of fiction readers. This readership's enthusiasm for fiction was apparently boundless - at a conservative estimate, by about 1905 at least 50,000 words of new magazine fiction was being published each week in Irish story papers alone, not counting that appearing in newspapers or the large-scale imports of British magazines. ${ }^{7}$ Some of this was bought from well-known international authors, most likely through the syndication agencies such as Tillotson's Fiction Bureau, which were an important part of the globalised circulation of popular fiction. ${ }^{8}$ Other stories were by professional Irish writers, including Rosa Mulholland and Katherine Tynan, for whom the Irish story papers were obviously an important and regular outlet for their work. Still others were submitted by readers as entries to the extremely popular story competitions run by most of these papers - the popular eagerness to write as well as read fiction being one more indication of the 'rage for narrative' represented by the story papers and cheap books of the early twentieth century. ${ }^{9}$

\section{SOCIAL PURITY AND THE POPULAR PRESS IN IRELAND}

However, reading was not an unquestionably applauded activity in the early twentieth century. It is probably not a coincidence that the 'anti-vice' or 'purity' movement in Ireland first turned its full attention to reading matter at this moment, a shift in focus marked by the establishment of the Catholic Truth Society of Ireland in 1899. For the previous twenty years or so of the purity movement's activities in Ireland, it had tended to be focused upon prostitution and sexual 'vice', especially that to be found in Dublin's notorious 'Monto' district, where brothels operated openly. ${ }^{10}$ The White Cross Vigilance Association operated a number of vigorous campaigns against these brothels, the typical strategy being to patrol the pavements outside them, approaching men as they entered and left the buildings and attempting to identify (and therefore shame) them. This strategy which the White Cross Association claimed was successful - was to be adapted for use against newsagents a few years later, as will be discussed below. Certainly by the early twentieth century 'pernicious literature' was the principal target of such organisations. ${ }^{11}$ 
The earlier anti-vice societies, of the kind which had picketed brothels in the Monto, were overwhelmingly Protestant and, in effect, Irish branches of British organisations. But as the campaign shifted towards reading matter, it also became predominantly Catholic, led by organisations such as the Catholic Truth Society of Ireland and later the Irish Vigilance Association, which was established in 1911 by Fr Richard Devane, SJ. ${ }^{12}$ The Catholic Truth Society was dedicated to the publication and distribution of what it described as 'cheap publications [and] sound Catholic literature in popular form so as to give instruction and edification in a manner most likely to interest and attract the general reader'. ${ }^{13}$ They were well-connected and wellfunded, and by 1903 had already distributed 1.5 million copies of their publications throughout the British empire. ${ }^{14}$

Like the vigilance movement, the Catholic Truth Society saw the commercial publishing industry as a powerful enemy, recognising the enormous popularity of fiction, and showing a particular antipathy to imported publications. At their first conference, held in 1903, the Society's secretary was reported as saying that, 'Story books ... were the very battleground on which the fight must be waged of pure and sound literature against the infidel and immoral publications ... it is by the seductive but filthy tales of the publications imported from England that the minds of our youth are corrupted'. ${ }^{15}$ This was an early indication of the ways in which Catholic-led drives against the 'immorality' of imported publications would work in close parallel with nationalist objections to their foreign cultural influence.

Douglas Hyde had inveighed against 'penny dreadfuls, shilling shockers and, still more, the garbage of vulgar English weeklies like Bow Bells and the Police Intelligence' in his 1893 'The Necessity for De-Anglicizing Ireland', but such statements had become commonplace in Ireland by the turn of the new century. ${ }^{16}$ D.P. Moran's objections to English 'gutter literature', especially that of 'penny papers ... saturated with grossness and which mainly circulate among boys', in his famous column in The Leader in September 1900 were later echoed by the scathing depiction, in his novel Tom O'Kelly, of Anglicisation via English publications in the fictional Ballytown, whose residents eagerly purchased copies of Tit Bits, the London Reader, and the Police Gazette, all of which were particular targets of anti-vice campaigners. ${ }^{17}$ In 1906, Arthur Griffith's journal Sinn Fein published attacks by Oliver St John Gogarty on 'filthy publications' from 'Ugly England'. ${ }^{18}$ Such rhetoric had become embedded in conventional public discourse by the early years of the twentieth century - stock phrases such as 'pernicious literature' or 'indecent publications' having become a shorthand to indicate a certain worldview or political and religious position. Both Lord and 
Lady Aberdeen (Viceroy and Vicereine from 1905 until 1915) were committed anti-vice campaigners, and as Protestant Liberals and supporters of Home Rule, they had been allied to Gladstone's social purity commitments as well as to his position on the Irish Question.

The emphasis of the movements against 'pernicious literature' upon magazines and (a few years later) Sunday newspapers, rather than upon books, is striking. The social purity movements certainly did disapprove of 'immoral' books (particularly novels), and they targeted both publishers and printers. Most famously, this resulted in the publishers Maunsel \& Co refusing to print Joyce's Dubliners for fear of the National Vigilance Association - an incident for which Joyce at least believed Lady Aberdeen personally responsible. ${ }^{19}$ Nevertheless, the social purity campaigners' principal targets were popular - and cheap - publications, especially magazines and weekly or Sunday newspapers. These were of course the publications read by working-class or lower-middle-class Irish readers, the readership which had only become mass consumers of commercial publications within a generation or two. The sudden shift of social purity campaigning in Ireland from prostitution to reading might then be interpreted as a moral panic with a very strong class focus. The more religiously-inspired campaigners saw magazines such as Photo-Bits or the Police Gazette as being destructive of moral fibre especially among the younger and lower-class readers who (like female readers) were presumed to be easily led astray. The more politically-inspired campaigners saw British publications (along with other imported culture such as the music-hall) as damaging to the national fibre of such readers. A meeting of the Dublin Vigilance Committee in 1911 united these concerns when Rev. Myles V Ronan told the audience that they must 'save the purity of Irish hearts and homes at any cost', and that Irish morality was 'a precious heirloom', while a newsagent who was also a member of Sinn Fein assured listeners that he never stocked English Sunday papers. ${ }^{20}$

The battle to save the purity of Irish hearts and homes was waged using the strategies learned during the earlier battle against brothels in Dublin. The anti-vice campaigners seamlessly transferred these strategies from brothels to newsagents, and began regular campaigns of picketing, undercover visits, and demonstrations. At that Dublin Vigilance Committee meeting in 1911, Rev. Myles V Ronan insisted that their campaign 'must begin with the newsagents', although he also mentioned that he had already had a meeting with more than a hundred of Dublin's newsboys who had pledged to stop selling 'objectionable papers'. ${ }^{21}$ But in reality, by 1911 newsagents had been under sustained intimidation by social purity campaigners for several years. As early as 1902, following the first successful prosecution of a 
newsagent for selling 'indecent' publications, the triumphant Vigilance Committee 'launched a system of district committees to enable "every newsagent in the city" to be "visited and afforded an opportunity of voluntarily giving up the sale of objectionable papers, books and periodicals". The recalcitrant would be prosecuted, while the public were urged to "strengthen the hand of the Vigilance Committee by only supporting those newsagents in whose shops our Approbation Card is clearly displayed"'.22

By 1908, there also appears to have been a concerted effort (by both the police and purity campaigners, particularly the Ancient Order of Hibernians in this instance) to prosecute newsagents who were selling 'indecent' picture postcards. This campaign had actually been prefigured by a series of letters and editorials two years earlier in the Irish Packet magazine, in which readers (and the editor, Matthias McDonnell Bodkin) complained about what they claimed was the fairly open sale of unwholesome postcards in some Dublin newsagents. One reader had written to claim:

I was in a shop the other day when a young masher came in and asked for some spicy postcards. He was shown a packet or two which apparently did not satisfy him. Are these the worst you have? he asked. Oh, no, said the smiling attendant - a young girl, too, more shame for the proprietor or manager of the shop. She got out some other packets, and from where I stood at the counter I could not help seeing they were grossly indecent. The masher purchased several packets... . ${ }^{23}$

The letter-writer also insisted that the authorities were doing nothing to prevent this trade. By 1908 however, the Ancient Order of Hibernians' campaign of visiting shops and confiscating and reporting 'indecent' postcards was resulting in multiple prosecutions. On 13 April that year, the Southern Police Court heard the cases against eight newsagents and stationers in Dublin accused of breaching the 1889 Indecent Advertisement Act. One of the interesting features of these prosecutions is that, unlike the incident supposedly witnessed by the Irish Packet's correspondent, the cards being sold by the defendants were not being kept under the counter, but were 'exhibit[ed] to public view in the windows' of their shops. ${ }^{24}$ Inevitably no description of the cards was ever given in 'respectable' newspaper reports of such prosecutions, so we have no definite knowledge of what the offending images were, although some phrases used in court do make it clear that they were certainly female nudes. ${ }^{25}$

The peak years for social purity campaigns against 'pernicious literature' in Ireland were from 1911 until 1913 (after which the 
vigilance movements began to shift their attention to cinema, itself perhaps evidence of their extremely accurate eye for popular culture). Picketing of newsagents - and the particular targeting of Eason and Sons Limited as the country's main wholesale supplier of newspapers and magazines - became a more frequent activity across all of Ireland from 1911. These were not small-scale or quiet events, either. Over the two or three years of most intense campaigning against 'immoral' publications, some small shops were subjected to crowds of several hundred protesters, windows were defaced and broken, and publications were confiscated and even burned at public demonstrations.

Limerick was a focus of particularly intense campaigning against British imports, especially of the News of the World, a Sunday newspaper of considerable popularity not only with Irish readers, but also with the enormous number of British troops stationed in Ireland in the early twentieth century. It was seen as exemplifying the worst excesses of sensationalist reporting of crime and divorce cases, although as L.M. Cullen has pointed out, its popularity with British troops here may well have been because it was their fastest way of getting the Saturday English football results. ${ }^{26}$ A particularly active Vigilance Committee was formed in Limerick, organised by a Father O'Connor, and they obtained pledges not to sell 'objectionable' newspapers from twenty-two newsagents in and around the city, as well as from the local newsboys. ${ }^{27}$ This action was praised in writing by Lord Aberdeen to the British National Vigilance Association meeting in London in October 1911, concluding, 'The fine example of Limerick may well be quoted as illustrating that there is no need for any community to submit tamely to the injurious incursions of an evil trade. ${ }^{28}$ The following Sunday - perhaps encouraged to believe they had the support of the authorities, following such a statement of unconditional support by the Viceroy - a crowd of demonstrators estimated at several thousand gathered at Limerick station to meet the train bringing Sunday papers directly from Rosslare, on behalf of Eason and Son, who had the wholesale contracts for most British papers imported into Ireland. This crowd was determined, as the Limerick Leader described it the following day, to 'make a strong protest against the literary rubbish which the English filth vendors have been dumping on the city for the past few years. ${ }^{29}$ When the train arrived, the mob seized the papers, took them to the People's Park where they were set on fire, after which the crowd was addressed by the local priest. A large crowd also jostled the soldiers who had arrived at Limerick station to collect their parcel of papers, and 'they were hustled about for a few minutes, but not seriously assaulted. The papers ... were taken from them and torn into shreds by the people. 
The road was quickly carpeted with torn papers, thrown by the angry crowds into the gutter - their rightful place. ${ }^{30}$

The following week, a large public meeting in Dublin established the Dublin Vigilance Committee, which would go on to be the driving force of the movement. The speakers inveighed against the British Sunday papers' coverage of divorce and criminal cases 'with full details', and a newsagent told the meeting that 'close upon 40,000 English Sunday newspapers were distributed in Dublin and suburbs each week. Taking the members to each family, that meant 200,000 people had this pernicious literature brought before their eyes.' He added that newsagents were typically 'not up to usual intelligence of other trades' because 'as a general rule they were women'. D.P. Moran also addressed the meeting, which ended with commitments to monitor newsagents' shops throughout the city. ${ }^{31}$ By November 20 that year, the Tyrconnell Club meeting in Strabane, Donegal had passed a motion commending the events in Limerick, a public meeting to establish a vigilance committee had been held in Galway, and the 'crusade against immoral literature' had been mentioned in the pulpit in Wexford and Bantry, where the Very Reverend Canon Coholan insisted that readers 'had their Irish newspapers and magazines to select from, which, as a rule, contained nothing dangerous to either faith or morals. ${ }^{\prime 32}$ Before the end of 1911 therefore, the campaign against 'immoral' literature in Ireland had become national, although it would be the Dublin Vigilance Committee which became the largest and most influential, in part probably because of its proximity to the headquarters of Irish national papers. By the following year, the Dublin Vigilance Committee was able to stage a 'monster meeting' at the Mansion House, addressed by Lord Aberdeen and attended by more than 20,000 people. ${ }^{33}$

\section{BRITISH FILTH AND IRISH PURITY}

The social purity movement's focus upon imported publications allowed it to unite both religious and nationalist sympathies to form a powerful force in early twentieth century Irish life. For nearly two years, from the seizing and burning of newspapers in Limerick to the fairly regular intimidation of newsagents in Dublin and beyond, the activities of the vigilance committees and their supporters appear to have been tolerated by the authorities. Public figures and most publications adopted an almost uniformly approving or appeasing tone, and stock phrases fulminating against 'filthy publications' invading Irish shores became common-place in public statements of all kinds.

Indeed, it is noticeable how little publicly-voiced opposition there was to the entire social purity project. One of the only really defiant stances towards the vigilance movement was that taken by the 
emphatically Tory society paper, Irish Life. It was Irish Life's penchant for photographs which prompted confrontation with the social purity movement. During the summer of 1912, its first year of publication, Irish Life regularly published large photographs of 'bathing beauties', most of which were bought from Underwood and Underwood, an international photographic agency. A typical example included 'On the Rocks' published on 9 August 1912, showing a young woman in a bathing costume which reveals her bare arms and legs, as well as the outline of her figure, sitting on rocks; the picture is captioned 'A Glimpse on the Sea Front at Broadstairs'. ${ }^{34}$ Photographs such as these (mostly bought from the same agency, and of a kind with those appearing in many popular British magazines) appeared for several weeks, until 16 August 1912 when the magazine announced that they had received a letter of complaint about the images from the Dublin Vigilance Committee. What distinguished Irish Life from almost all other Irish publications was their aggressively derisive response to this complaint. Where suppliers such as Easons, and publishers such as Maunsel, sought to appease social purity campaigners at every turn, Irish Life published a number of satirical attacks upon them. This began when the magazine commented with reference to the 'bathing beauties' photographs that they were of natural bodies, and that '... Nature ... had existed before Vigilance Committees were thought of, and would continue when they had been forgotten.' For good measure, this column was completed with a photograph of two young children in shorts playing on a beach, and captioned 'Quite Happy! Provided There Are No Vigilance Committees to Object' ${ }^{35}$

Irish Life's unusual willingness to resist the demands of social purity campaigners was motivated by conservatism, rather than radicalism. The magazine was opposed to Home Rule, the Liberal Party, and, therefore, Lord and Lady Aberdeen's tenure in the Vice-regal Lodge. Its decision to not only resist, but also ridicule the social purity movement was therefore entirely in keeping with its other attacks upon both of the Aberdeens. Their closeness to Gladstone and his views on Irish Home Rule was of a kind with the very Liberal belief they had shared with him in the improvability of both individuals and society as a whole. Conservative ideology, by contrast, not only saw such campaigns as unwarranted interference in private affairs, but also rejected the inherent belief in a more democratic and open society which underpinned Liberal commitments to social improvement. The Conservative opposition to the social purity movement therefore serves as a useful reminder that, at the time, these campaigns were perceived to be progressive rather than conservative, and were intrinsically connected to the Liberal belief in the need to expose and eradicate social ills (such as pornography) in order to build a 
better society. In a specifically Irish context, the social purity campaign became intrinsically linked to the Home Rule movement, and its determination to establish Irish political independence.

In 1913, the courts did issue a mild rebuke to some of the more intimidatory tactics used by some social purists. Two members of a crowd of up to 300 were convicted and fined $£ 1$ each for obstructing the street during a protest against British Sunday newspapers - they had gathered outside the shop of Francis Dettinger on Dorset Street in Dublin, threw mud across the shop window and prevented customers from entering the premises. ${ }^{36}$ The Irish Times was also losing patience with the tone and tactics of the social purists - in May 1913, they published a column based upon a 'manifesto' recently circulated by the Dublin Vigilance Committee, which they sarcastically described as a 'literary treat'. It went on, 'There are ... passages which a sense of delicacy prevents us from quoting. But we learn that "the gutter-Press of England is flooding our shores with a nauseous tide of seductive debauchery" that "hearts are blighted and minds are poisoned in city and hamlet" and that a "plague with eternal consequences is allowed to stride through the land like a hellish monster, distributing death-dealing contagion on every side." We were not aware of this. ${ }^{37}$ The following month, the paper also complained that the Vigilance Committee had a history of making 'a series of fierce, but vague, charges', and pointed out this was probably because naming specific publications they condemned would have resulted in libel proceedings being brought against them. ${ }^{38}$

The vagueness of social purity warnings against the 'nauseous tide of seductive debauchery' served another important purpose, as well as that of avoiding libel writs. It also allowed the threat from such publications to be constant and on-going, but without requiring any specific examples, any one of which might not have seemed particularly debauched to many readers, thus undermining the force of warnings about the 'nauseous tide'. It also, in its almost universal assignment of blame to British publications, was largely guaranteed to receive favourable coverage from Irish publications, and it further gave those Irish publications a certain degree of 'cover' for their own contents. It is notable, for example, that it was during the very peak of social purity concerns with reading matter, which included a particular focus upon publications which printed 'hideous advertisements of patent ways of recovering from indulgence' (as Gogarty had described them in his 1906 article in Sinn Fein), that Ireland's Own magazine began publishing regular advertisements for precisely those kind of products - including both tablets and electric devices - promising to 'restore lost vigour'. ${ }^{39}$ Aside from the advertising they published, all of the Irish story papers including 
Ireland's Own, the Irish Packet, and the Irish Emerald, published stories throughout the early twentieth century which were sensationalist, lurid, and frequently violent. That they felt able to do this while claiming to be wholesome and patriotic - and appear to have attracted absolutely no attention from social purists - suggests that the anti-vice campaign's almost exclusive focus upon English publications allowed Irish magazines a useful latitude.

In this respect, a comparison with the British purity movement and the responses to it by the popular press, is instructive. British campaigners had of course also targeted the popular press, and from an early date. In 1888 Samuel Smith MP had proposed a resolution to the House of Commons against 'the rapid spread of demoralising Literature in this Country', and in 1889 the Indecent Advertisements Act was passed largely in order to control advertisements (usually for birth control or appliances claiming to improve sexual performance) in popular magazines. ${ }^{40}$ What is particularly notable about these developments and the motivations driving them was that the campaigners were overwhelmingly concerned about 'indecencies from abroad', specifically France. This was reflected in one of the most wellpublicized prosecutions relating to the issue, that of the publisher Vizetelly for publishing Zola in 1889. In late Victorian and Edwardian England, the adjective 'French' when applied to almost any object or practice, appears to have stood as a popular shorthand for indecency, dissolution, and a particularly sexualised behaviour. This is particularly ironic considering that the 'penny dreadful' magazines were, of course, largely published in London. Even more ironic was the response of one of the most successful of those London publishers, the Harmsworth company (publisher of the enormously successful Answers and Comic Cuts). Rather than attempting to resist the social purity movement, Harmsworth capitalised upon it, introducing several new story papers (almost all aimed at young male readers, but probably read more widely too, as were the Irish penny weeklies) such as the Halfpenny Marvel and Pluck, which he termed 'penny healthfuls'. As Katherine Mullin has argued,

... Harmsworth's boys' papers were carefully pitched to cash in on social purity anxieties over children's reading. Editorials ventriloquized 'penny dreadful' debates, jostling for position with other papers in a fiercely competitive market by mimicking social purity rhetoric and deflecting it towards their rivals. 'You need not be ashamed reading this!', 'Nothing but pure healthy literature', 'No More Penny Dreadfuls: These Healthy Stories of Mystery and Adventure Will Kill Them' ... were the taglines for Harmsworth boys' papers. ${ }^{41}$ 
The Irish story papers were operating in an even more fiercely competitive market than the English ones, precisely because of the added competition (into an already small market) from those English papers. It should perhaps be no surprise then that the Irish papers aimed at a lower-middle-class and Catholic readership generally adopted a similar approach to Harmsworth's in co-opting much of the rhetoric of social purity in order to claim that their publications were-unlike the degenerate filth of always-unnamed English magazines - wholesome and improving. Not only that, but because the unwholesome was always located in imported British magazines, Irish publications were fairly easily able to position themselves in direct and nationalist contrast to their British competitors, thus borrowing the rhetoric of patriotism as well as social purity. In effect then, in Ireland and for Irish magazines, Britain and British popular culture's threat to Irish moral integrity was a useful equivalent to the dangers of Frenchness as it was perceived in Britain.

Just as was the case with Harmsworth's 'penny healthfuls' in Britain, however, the claims of wholesomeness and purity did not necessarily need to be any more than rhetorical for the Irish magazines. Brandon Kershner points out for example that the very issue of the Halfpenny Marvel which carried a testimonial from a clergyman to its being 'wholesome in tone', also carried a cover illustration 'of a man being tortured, with the caption "The gaoler screwed up the horrible machine until the brigand's bones were nearly broken and he shrieked aloud for mercy, though none was shown"', 42 This is very similar to some of the Irish story papers, which vigorously self-described as being wholesome and 'ennobling' (as Ireland's Own put it), yet simultaneously published stories of violence, murder, and 'immoral' relationships.

Certainly, the extent to which the Very Reverend Canon Coholan's claim that Irish magazines '. . a as a rule, contained nothing dangerous to either faith or morals' was accurate is worthy of some examination. The implication of this statement, as with so many claims by the broader vigilance movement, was that the Irish story papers contained material which was significantly more wholesome, patriotic, and improving than that published in the English magazines. The vast output of fiction - as mentioned above, more than 50,000 words of fiction per week was appearing in the Irish penny weekly papers alone by the early years of the twentieth century - means that for the most part, only general comparisons can be made. However, even these are enough to cast doubt upon Canon Coholan's assertions of the purity of Irish stories.

Certainly, there were no Irish equivalents to British publications such as Photo-Bits, in terms of either format or tone. As its name 
suggests, Photo-Bits had a strong reliance on photography, whereas the Irish story-papers (especially the penny-weekly papers such as Ireland's Own or the Irish Emerald) almost never published photographs, and indeed were published on low-quality paper not really compatible with photographic illustrations. Photo-Bits was embroiled in several scandals during the early twentieth century, its content having become much more sexually explicit during 1909 in particular, when it published a number of photographs related to cross-dressing, fetishism, and erotic discipline. ${ }^{43}$ No Irish publication published anything approaching this kind of material, of course, although Irish Life's photographs of 'bathing beauties' were of a kind quite similar to Photo-Bits' non-fetish illustrations.

The contents of the short and serial fiction published in Ireland's story papers, however, would not appear to have been substantially different from much of that published in equivalent British papers. For the most part, as in the British papers, they were merely sensationalist in tone, but that sensationalism could be extreme. There were, for example, countless stories featuring shipwrecks, train crashes, and violent attacks by Native Americans, Cromwell's troops and Caribbean pirates, as well as the schemes of wicked uncles, cruel step-mothers, gold-digging suitors, and cold-hearted land agents, depending upon the genre of story. While sexual relationships were rarely made explicit, there were numerous references to mistresses, 'fallen' women, and broken marriages, all of which were precisely the kind of plot-lines objected to by the vigilance movement. Physical violence was a great deal more explicit, and occasionally in sexualised contexts. In 1906, for example, Ireland's Own published 'The Millions of a Mill Girl' by C.J. Hamilton (a moderately successful writer of Irish family, best known for having published Notable Irishwomen in 1904), which opens with the heroine, a Belfast mill girl, witnessing one of her colleagues being accused by her suitor of flirting with other men. She vigorously defends herself, but 'the next minute he had thrown her on the ground; he had taken the hatpin out of her head, and was digging it into her brain with his full force. ${ }^{44}$ In 1911, the Emerald magazine published a story set during the Indian Mutiny, which not only featured European women being killed by their own menfolk in order to spare them being captured (and, by implication, raped) by Indian soldiers, but also a scene in which a 'huge Sepoy' seizes a small English child by the foot and,

dashed him against the nearest wall, amid the laughter and cheers of his comrades, whose brutal merriment drowned the shriek of mortal terror the little fellow gave ere he was rendered senseless. He was somebody's golden-haired darling. 
Somebody would have laid down their life for him to save him from this fate. But he lay still on the road at his destroyer's feet, the red blood dying his fair hair and little innocent face, while the huge brute laughed as he kicked him aside. ${ }^{45}$

As well as sex and violence, there was a particularly strong - and strongly sensationalist - emphasis upon race in many stories. As in the example cited above, this emphasis was particularly evident in stories set in the British empire, but also appeared in many other contexts, such as American stories of the frontier, like 'The DeathSeeker; or, Fighting Horace, Roughrider' by A Roucollie, published in the Shamrock and Emerald in 1912, presumably having been bought from an American syndication bureau. An adventure story, it focused heavily on violent and denigrating depictions of African-American servants, and even made reference to the 'half-breed' wife of one of the villains, with an authorial interjection that many men would not even have been prepared to support 'such women'. ${ }^{46}$ However, lurid depictions of race were also to be found in stories set in Ireland and Britain. A detective story set in Belfast, entitled 'The Case of the Mysterious Tooth-marks' published by Ireland's Own in 1908, featured a series of gruesome murders in which the victims were found to have 'two punctures on the back of the neck an inch or so apart, looking swollen and angry.' The perpetrator is eventually discovered to be the black slave of an American resident in the area - not only that, but a slave who belongs to a 'special race' with a poisonous bite, akin to that of a snake. The murderer is tracked - with dogs - across the Ulster countryside in a scene obviously intended to be reminiscent of slave-tracking in the American South, before finally being cornered, when '... they saw a hideous face ... a man-like ape or an ape-like man. The face was drawn with terror or exhaustion, and smeared with blood, but what struck them with horror, above all, was the mouth, blubber lipped and half open, from which protruded two long gleaming wolfish fangs. ${ }^{47}$ These kind of stories, while certainly not prosecutable under law, were undoubtedly the type of sensation fiction (mainly aimed at younger readers) which was being roundly condemned by the campaign against pernicious literature when it appeared in British papers. It is certainly difficult to believe that the Very Reverend Canon Coholan, speaking from his pulpit in Bantry in 1911, was thinking of such stories when he commended Irish magazines to his parishioners.

The fact that Irish magazines were publishing both advertising and fiction of a kind condemned by the vigilance movement at almost precisely the same moment that the movement was holding some of its largest meetings is particularly noticeable. Shortly after Lord Aberdeen 
addressed the 'monster meeting' of the Vigilance Committee at the Mansion House in Dublin in July 1912, Ireland's Own were advertising Damoroid Tablets, which not only promised to 'keep you young' but also to overcome 'earlier mistakes'; a widely-understood code for sexual misdemeanours ranging from masturbation to promiscuity. ${ }^{48}$ Indeed, during the very height of the social purity movement in Ireland, between 1911 and 1913, Ireland's Own in particular was regularly publishing advertisements which might very well have been prosecutable under the 1889 Indecent Advertisements Act, given that some of them promoted products claiming to alleviate a 'complaint or infirmity arising from or relating to sexual intercourse'. ${ }^{49}$

Despite the noticeable gap between the vaunted purity of Irish story papers and the material they actually published, there appear to be no instances of social purity complaints, boycotts, or even public criticism of these publications. Instead, public statements and organised campaigns focused on imported British newspapers and magazines. This suggests that not only did Irish magazines find it useful to mimic the rhetoric of social purity, but also perhaps that the National Vigilance Association found it useful to focus that rhetoric upon 'foreign' publications - meaning that the magazines and campaigners may have inadvertently developed a symbiotic relationship.

\section{CONCLUSION}

The energies of the vigilance committees had begun to shift away from publications and towards the 'picture palaces' by 1913. In June of that year, a meeting of the Dublin Vigilance Committee condemned the 'suggestive and bad' shows at some picture palaces, and said 'that it ought to be a very serious consideration whether the management of those cinematograph performances ought to be allowed to continue'. ${ }^{50}$ By 1915, vigilance campaigners had attempted a (not very successful) protest during a screening of Neptune's Daughter at the Bohemian Theatre in Phibsborough, and become involved in controversies regarding the censorship of film posters. ${ }^{51}$ Neptune's Daughter starred Annette Kellerman, billed on some posters for the film as 'the perfect woman', and wearing little more than a mermaid's tail for most of the movie. Indeed, her scantily-clad swimming and beach scenes are quite reminiscent of the commercial 'bathing beauties' photographs in Irish Life which had also provoked objections from the vigilance campaigners. $^{52}$

This shift of focus towards the content of film and film advertising also perhaps indicates a shift of popular activity among the Irish public, as the purity campaigners did appear to have accurate instincts for the popular, even as they condemned it. However, this does not necessarily indicate a straightforward popular support. The reported 
crowd of 20,000 at the 1912 Mansion House meeting, and even the smaller but still significant crowds which seized and destroyed copies of the News of the World in Limerick, suggest that the vigilance movement could, on occasion, muster enthusiastic support from the Irish public. This does not, however, mean that they stopped buying the imported magazines. Circulation figures for any publications in Ireland at this time are rarely available and often not reliable. However, there is no clear indication that even the peak years of purity campaigning resulted in any drop in sales of any British publications in Ireland.

The other important conclusion to be drawn is about the supposedly 'wholesome' qualities of the Irish story papers such as Ireland's Own. This Irish wholesomeness is implied by the vigilance movement's focus on British papers, and of course by their own earnest repudiations of 'pernicious literature' and claims to be providing a 'healthful' alternative. But, as I have already suggested, Irish publishers and the vigilance movement appear to have developed a symbiotic relationship in this respect. Certainly it was politically expedient for vigilance campaigners to focus their attacks upon British publications circulating in Ireland. This ensured they could make colourful attacks upon 'nauseous tides of seductive debauchery' without suggesting that the Irish people themselves were either seduced or debauched; suggestions which might not have been popularly received. It was even more expedient for Irish publishers to support a campaign to boycott their powerful British rivals, of course, and from both of these expediencies followed the claims that the Irish story papers were 'wholesome' alternatives to the filthy tide of British smut.

From a historical perspective, a tendency to take at face value the claims of wholesomeness made about Irish publications may account for the lack of more recent scholarly interest in those papers and magazines. The lack of controversy about Irish publications especially by comparison to the noisy pickets and mob attacks upon British papers - of course encouraged later generations to take the Irish story papers at their own estimation. Certainly, they didn't have the risque photographs of magazines like Photo-Bits, or even those of the Tory Irish Life. But, presumably motivated by their knowledge of the market for sensational and often violent stories, they took the same approach as Harmsworth's 'penny healthfuls', by loudly declaring wholesomeness while consistently publishing the rather less wholesome material their readers actually demanded. It is also worth noting in final conclusion that Irish readers may themselves have found this arrangement expedient, allowing as it did for a public stand against 'pernicious literature' and a display of national pride, while continuing to read the entertaining stories they enjoyed. 


\section{NOTES}

1. Some of the large body of scholarship on this era of British popular publishing includes Laurel Brake, Bill Bell, and David Finkelstein, eds., Nineteenth-Century Media and the Construction of Identities (Basingstoke: Palgrave, 2000), Margaret Beetham, A Magazine of Her Own?: Domesticity and Desire in the Woman's Magazine, 1800-1914 (London: Routledge, 2005), and Kate Jackson, George Newnes and the New Journalism in Britain, 1880-1910: Culture and Profit (Ashgate: Aldershot, 2001).

2. See L.M. Cullen, Eason \& Son: A History (Dublin: Eason \& Son, 1989) for a comprehensive history of the company.

3. See Kate Jackson, 'The Tit-Bits Phenomenon: George Newnes, New Journalism and the Periodical Texts', Victorian Periodicals Review, 30.3 (1997), 201-26.

4. See Kelly Boyd, Manliness and the Boys' Story Paper in Britain: A Cultural History, 1855-1940 (Basingstoke: Palgrave Macmillan, 2003), and Helen A Fairlie, Revaluing British Boys' Story Papers, 1918-1939 (Basingstoke: Palgrave Macmillan, 2014).

5. See Marie-Louise Legg, Newspapers and Nationalism: The Irish Provincial Press, 1850-1892 (Dublin: Four Courts Press, 1999), Kevin Rafter, Irish Journalism Before Independence: more a disease than a profession (Manchester: Manchester University Press, 2011), Simon Potter, Newspapers and Empire in Ireland and Britain: Reporting the British Empire, c.1857-1921 (Dublin: Four Courts Press, 2004), and Margot Backus, Scandal Work: James Joyce, the New Journalism, and the Home Rule Newspaper Wars (South Bend, Indiana: Notre Dame University Press, 2013).

6. Our Boys, a story paper started by the Christian Brothers in 1914, is discussed in Michael Flanagan, 'To Enlighten and Entertain: Adventure Narrative in Our Boys', Irish Communications Review, 12 (2010), 88-102. Brian Griffin, Cycling in Victorian Ireland (Dublin: Nonsuch Press, 2006) includes some discussion of the Irish Cyclist magazine, and there is fairly extensive discussion of Lady of the House, the most widely-circulated Irish women's magazine, in John Strachan and Claire Nally, Advertising, Literature and Print Culture in Ireland, 1891-1922 (Basingstoke: Palgrave Macmillan, 2012).

7. The fiction published weekly by Ireland's Own, the Irish Packet, and the Irish Emerald alone would have amounted to at least 50,000 words a week.

8. See Christopher Hilliard, 'The Provincial Press and the Imperial Traffic in Fiction, 1870s-1930s', Journal of British Studies, 48.3 (2009), 653-673, for a detailed discussion of the ways that syndication bureaux influenced the global circulation of fiction.

9. See Stephanie Rains, 'Going in for Competitions': Active Readers and Magazine Culture, 1900-1910', Media History, 21.2 (2015), 138-49, for discussion of competitions in Irish publications.

10. Katherine Mullin, James Joyce and Social Purity (Cambridge: Cambridge University Press, 2007), p.184.

11. Katherine Mullin, 'Irish Chastity: British social purity associations and Ireland', in Associational Culture in Ireland and the Wider World, ed by R.V. Comerford and Jennifer Kelly (Dublin: Irish Academic Press, 2010), p.144.

12. Mullin, 'Irish Chastity', p.147.

13. Cited in Anthony Keating, 'The Uses and Abuses of Censorship: God, Ireland and the Battle to Extend Censorship Post 1929', Estudios Irlandeses: Journal of Irish Studies, 9 (2014) [online, accessed August 2014].

14. Supplement to The Tablet, 24 October 1903, p.669.

15. Supplement to The Tablet, 24 October 1903, p.670.

16. Cited in R. Brandon Kershner, The Culture of Joyce's Ulysses, (Basingstoke: Palgrave Macmillan, 2010), p.4.

17. D.P. Moran, Tom O'Kelly, (Dublin: Cahill and Co., 1905), p.208.

18. Oliver St John Gogarty, 'Ugly England I', Sinn Fein, 15 September 1906, p.3. 
19. Mullin, James Joyce, p.14.

20. 'Evil Publications', Irish Independent, 6 November 1911, p.6.

21. 'Evil Publications', p.6.

22. Mullin, 'Irish Chastity', p. 145.

23. 'Chat with the Editor', Irish Packet, 6 January 1906, p.366.

24. Irish Times, 14 April 1908, p.8.

25. Irish Times, 14 April 1908, p.8.

26. Louis Cullen, Eason and Son: a History (Dublin: Eason \& Son, 1989), p.253.

27. 'Lord Aberdeen and "Objectionable Newspapers"', Irish Times, 26 October 1911, p.5.

28. 'Lord Aberdeen and "Objectionable Newspapers"', Irish Times, 26 October 1911, p.5.

29. 'Limerick's War', Limerick Leader, 30 October 1911 p.3.

30. 'Limerick's War', Limerick Leader, 30 October 1911 p.3.

31. 'Meeting in Dublin', Freeman's Journal, 6 November 1911, p.8.

32. 'The Crusade Against Immoral Literature', Freeman's Journal, 17 November 1911, p.11, 'Immoral Literature', Southern Star 18 November 1911, p.5, and 'Donegal Takes Action', Freeman's Journal 20 November 1911, p.8.

33. 'Suppression of Immoral Literature: Meeting at the Mansion House', The Irish Times, 6 July 1912 p.10.

34. Irish Life, 9 August 1912, p.791.

35. 'Disillusioned', Irish Life, 16 August 1912, p.840.

36. 'Dublin Obstruction Charge', Irish Independent, 4 February 1913, p.5.

37. 'The Vigilance Committee', Irish Times, 31 May 1913, p.6.

38. 'The Vigilance Committee', Irish Times, 9 June 1913, p.4.

39. Oliver St John Gogarty, 'Ugly England I', p.3.

40. Cited in Samuel Hynes, The Edwardian Turn of Mind (Princeton: Princeton University Press, 1968) p.257.

41. Mullin, James Joyce, p.39.

42. R.B. Kershner, Joyce, Bakhtin and Popular Literature: Chronicles of Disorder (University of North Carolina Press, 1989), p.33.

43. See Jennifer Burns Levin, 'How Joyce Acquired the "Stale Smut of Clubmen": Photo Bits in the Early Twentieth Century', James Joyce Quarterly, 46.2 (2009), 255-268, for a full discussion of the fetish photographs in Photo Bits.

44. C.J. Hamilton, 'The Millions of a Mill Girl', Ireland's Own, 10 January 1906, p.8.

45. Madeline Cummins, 'Was it Betrayal? Or, The Conjuration of Abdul Sing', Irish Emerald, 15 July 1911, p.3.

46. A. Roucollie, 'The Death-Seeker; or, Fighting Horace, Roughrider' by A Roucollie, Shamrock and Emerald, 17 August 1912, 17-20.

47. F. Morrough O'Brien, 'Dermot O'Donovan, The Great Irish Detective. 3. - The Case of the Mysterious Tooth-marks', Ireland's Own, 1 April 1908, p.17.

48. 'This Man Is Young at 55 Years. He is a "Damaroid Man"', Ireland's Own, 4 September 1912 p.20.

49. Cited in Hynes, The Edwardian Turn of Mind, p.256.

50. 'The Vigilance Committee', Irish Times, 14 June 1913, p.16. For a fuller discussion of the Irish Vigilance Association's early responses to cinema, see Denis Condon, Early Irish Cinema 1895-1921, (Dublin: Irish Academic Press, 2008), pp.227-36.

51. "Neptune's Daughter": Protest in Dublin Picture House', Irish Times, 9 July 1915, p.6, and 'Dublin Poster Censorship Committee', Irish Times, 29 October 1915, p.8.

52. Neptune's Daughter, dir. Herbert Brenon (USA: Universal Film Manufacturing Company, 1914). 